Journal of Extension Education

Vol. 29 No. 1, 2017

DOI:https: //doi.org/10.26725/JEE.2017.1.29.5780-5786

\title{
Adoption of Crop Insurance Schemes in Tamil Nadu
}

\section{Karthick ${ }^{1}$, A. Anbarassan ${ }^{2}$ and C. Cinthia Fernandaz ${ }^{3}$}

\begin{abstract}
The study was conducted in Southern zone of Tamil Nadu a constituent state of India. One hundred and eighty farmers who had adopted crop insurance schemes were selected through random sampling procedure. The respondents were interviewed using a pre-tested questionnaire for identifying factors influencing and constraints in adoption of crop insurance schemes. The study revealed that lack of scope for crop diversification and definite crop loss due to adverse climatic condition were the major factors influencing the adoption of crop insurance schemes. The study inferred that lack of compensation from the crop insurance scheme, delayed payment of indemnity, lack of awareness about the scheme and lengthy procedure to avail crop insurance were the major constraints.
\end{abstract}

Keywords : Crop insurance; Factors; Constraints; Suggestion; Tamil Nadu

\section{INTRODUCTION}

Agricultural risk is associated with negative outcomes that arise from imperfectly predictablebiologicalvariables like outbreak of pest and diseases, adverse climatic factors like drought, flood and storm, resource risks like nonavailability or poor quality of inputs, and price risks, which altogether are not within the control of farmers (Mani et.al 2012). Managing risks in agriculture is a big challenge to the farmers, researchers and the policy makers. The, adoption of appropriate risk coping measures are the prerequisites to protect farm economy and stabilize farm income. Different strategies viz., providing tax reductions, waiving off loans and interest on loans, drought or flood relief measures, etc have been evolved by the government to combat the risks and uncertainties. However, a major hurdle in such types of relief is that they depend primarily on the policies as well as the resources of the government. Therefore, though these measures guarantee some security in a situation of uncertainty, it makes the farmers to wait in anticipation for some relief when there is a loss. Farmers, on the other hand, attempt to reduce

1. \& 3.Assistant Professors, Forest College and Research Institute, Tamil Nadu Agricultural University, Mettupalayam641301 and 2 Research Associate, Department of Agricultural Economics, Tamil Nadu Agricultural University, Coimbatore- 641003. 
risks by utilizing modern technology, diversifying the agricultural operations through intercropping, flexible use of fertilizers, pesticides, etc., (Mohanty \& Sandeep, 2012).

Crop insurance is one of the anticipatory adaptation measures proven worldwide as an effective institutional mechanism to overcome the adverse impacts of climate variability. helps in stabilization of farm production and income through promoting technology, encouraging investment, and increasing credit flow in the agricultural sector of the farming community. It helps in optimal allocation of resources in the production process. The basic principle underlying crop insurance is that the loss incurred by a few is shared among others in an area, engaged in a similar activity. Also, losses incurred in bad years are compensated from resources accumulated in good years. Crop insurance contributes to self-reliance and self-respect among farmers, since in cases of crop loss they can claim compensation as a matter of right. Thus, it cushions the shock of crop loss by assuring farmers' protection against natural hazards beyond their control. Realizing the importance of crop insurance as a tool for managing risk and uncertainties in agriculture, the present study was conducted to identify factors which are influencing the purchase of crop insurance products by farmers and constraints faced by farmers in adopting crop insurance.

\section{METHODOLOGY}

This study was conducted in Southern Zone of Tamil Nadu, which is highly vulnerable to climate change and variability (Palanisamy et. al., 2011). In Southern Zone, Pudukkottai, Virudhunagar and Sivagangai districts were selected purposively to represent the National Agricultural Insurance Scheme (NAIS), Weather Based Crop insurance scheme (WBCIS) and Modified National Agricultural Insurance Scheme (MNAIS) based on maximum number of farmers enrolled under crop insurance scheme during 2012-13. One block (Avuyadurkoil block in Pudukkottai district, Thiruchuli block in Viridhunagar district and Ilayankudi block in Sivagangai district) were selected purposively from each district based on maximum number of farmers enrolled for the crop insurance scheme. Primary data from the sample farms were collected with the help of a pre-tested interview schedule through personal interviews. A total of 180 farm households were randomly interviewed at the rate of 60 per district. The results were analyzed with the help of different statistical tools such as, percentage, and count.

\section{FINDINGS AND DISCUSSION}

There were many important qualitative factors that influenced the adoption of crop insurance scheme. Crop insurance formed a great support to resource poor farmers who had no alternatives other than borrowing under 
adverse situations. Eventhough the crop insurance scheme was in operation for a long time, there existed many speculations and scepticism among farmers about the scheme. Though the benefits of the scheme were well known, it still have not acheived the expected coverage from the point of view of either the implementing agency or the beneficieries. It would mean that the realisation of financial benefits out of the scheme was not the sole factor governing the adoption of crop insurance. Instead, there must be some other factors which might influence the adoption. The factors that influenced the adoption of crop insurance were identified and the results are presented in Table 1.

Table 1.

Factors Influencing the Adoption of NAIS, WBCIS and MNAIS

\begin{tabular}{|c|c|c|c|c|c|c|c|}
\hline \multirow{2}{*}{$\begin{array}{l}\text { S1. } \\
\text { No. }\end{array}$} & \multirow{2}{*}{ Particulars } & \multicolumn{2}{|c|}{$\begin{array}{l}\text { NAIS } \\
(n=60)\end{array}$} & \multicolumn{2}{|c|}{$\begin{array}{l}\text { WBCIS } \\
(n=60)\end{array}$} & \multicolumn{2}{|c|}{$\begin{array}{l}\text { MNAIS } \\
(\mathrm{n}=60)\end{array}$} \\
\hline & & $\begin{array}{l}\text { Mean } \\
\text { Score }\end{array}$ & Rank & $\begin{array}{l}\text { Mean } \\
\text { Score }\end{array}$ & Rank & $\begin{array}{l}\text { Mean } \\
\text { Score }\end{array}$ & Rank \\
\hline 1 & $\begin{array}{l}\text { Lack of scope for crop } \\
\text { diversification }\end{array}$ & 61.62 & 1 & 30.00 & 6 & 53.08 & 2 \\
\hline 2 & $\begin{array}{l}\text { Definite crop loss due to } \\
\text { adverse climatic condition }\end{array}$ & 54.02 & 2 & 62.53 & 1 & 60.92 & 1 \\
\hline 3 & $\begin{array}{l}\text { Aware of the benefits of crop } \\
\text { insurance scheme }\end{array}$ & 47.07 & 3 & 49.78 & 3 & \# & \# \\
\hline 4 & $\begin{array}{l}\text { Mandatory for availing crop } \\
\text { loan }\end{array}$ & 39.97 & 4 & 55.25 & 2 & 42.50 & 4 \\
\hline 5 & $\begin{array}{l}\text { Encouraged by the } \\
\text { experienced farmers }\end{array}$ & 37.52 & 5 & 42.67 & 4 & 34.57 & 5 \\
\hline 6 & Easy access to loan & 36.17 & 6 & 35.02 & 5 & 32.56 & 6 \\
\hline 7 & Financial Security & 0.0 & - & 0.0 & - & 50.52 & 3 \\
\hline
\end{tabular}

The lack of crop diversification was the important factor that influenced the adoption of NAIS (Pudukottai district) and MNAIS (Sivagangai district). Paddy was the only crop cultivated under rainfed condition in Pudukkottai district during rabi season. The main source of irrigation was tank water, and soil in the study block was sandy coastal alluviam which can withhold the rain water upto 1015 days. In this field condition, growing paddy crop alone was feasible. Farmers in the Sivagangai district cultivated paddy and chilies in larger area and cotton in 
smaller area under rainfed condition, if residual soil moisture was available.

In a situation of prolonged drought, farmers failed to cultivate crop and therefore, the spread of prosopis into the cultivable land made the land unfit for crop cultivation. Therefore, adoption of crop insurance offered the financial security (i.e., the indemnity that could be received in case of financial loss due to adverse weather parameters). Hence, lack of crop diversification was the major factor influencing the adoption of crop insurance. Farmers had a constant fear about crop loss due to adverse climatic conditions (either flood or drought or pest and diseases) and this was the important factor that influenced the farmers to adopt crop insurance in the study districts. The next important factor that influenced the adoption of crop insurance was awareness about the benefits of adopting crop insurance. Farmers felt that adopting crop insurance would minimise income loss occurred due to adverse weather events, pest and disease and so on. Crop insurance was mandatory to those farmers who were availing credit from institutional sources. At present, service for insurance to loanee farmers was provided by the institutions like Primary Agricultural Co-operative Credit Banks or commercial banks. Those farmers who availed crop loan from these institutions compulsorily came under insurance coverage. Encouragement by the fellow farmers who had already reaped the benefit of crop insurance and easy access of loan from financial institutions (Similar findings were observed in the study conducted by Manohari and Desai, 2015 in Tamil Nadu) were the other factors that influenced the adoption of insurance by the farmers.

\section{Constraints in the Adoption of Crop Insurance Scheme}

Farmers in the study area faced several constraints in taking up crop insurance. Therefore, it was important to identify such constraints so that necessary remedial measures can be taken to increase the enrolment of the farmers under such scheme. Based on the opinion of the selected respondents, the constraints were ranked and the results are presented in Table 2 .

It is observed from Table 2 that, lack of compensation from the NAIS to the farmers of Pudukkottai district so far, whatever be the yield loss was the major constraint in adoption of NAIS which was expressed by 90 per cent of the respondents.

Around 83 per cent of the farmers who had adopted NAIS revealed that they were not satisfied with the delay in indemnity settlement. The main reason for this was that the banks did not notify about claims at the appropriate time to the farmers (the claim settlement process took a very long time-normally six months and even one year in some cases) and therefore, farmers were unable to get compensation against their losses at right time. 
Table 2.

Constraints in Adoption of Crop Insurance Scheme

\begin{tabular}{|c|c|c|c|c|}
\hline $\begin{array}{l}\text { S1. } \\
\text { No. }\end{array}$ & Particulars & $\begin{array}{l}\text { NAIS } \\
(n=60)\end{array}$ & $\begin{array}{l}\text { WBCIS } \\
(n=60)\end{array}$ & $\begin{array}{l}\text { MNAIS } \\
(n=60)\end{array}$ \\
\hline 1 & Lack of awareness about the scheme & $\begin{array}{c}7 \\
(11.67)\end{array}$ & $\begin{array}{c}52 \\
(86.67)\end{array}$ & $\begin{array}{c}18 \\
(30.00)\end{array}$ \\
\hline 2 & Low premium paying capacity & $\begin{array}{c}10 \\
(16.67)\end{array}$ & $\begin{array}{c}15 \\
(25.00)\end{array}$ & $\begin{array}{c}31 \\
(51.67)\end{array}$ \\
\hline 3 & Availability of relief fund from the government & $\begin{array}{c}12 \\
(20.00)\end{array}$ & 0 & $\begin{array}{c}3 \\
(5.00)\end{array}$ \\
\hline 4 & Administrative reasons & & & \\
\hline a & Banks were not available nearby & $\begin{array}{c}13 \\
(21.67) \\
\end{array}$ & $\begin{array}{c}10 \\
(16.67)\end{array}$ & $\begin{array}{c}27 \\
(45.00) \\
\end{array}$ \\
\hline $\mathrm{b}$ & Difficulty in opening bank account & $\begin{array}{c}9 \\
(15.00)\end{array}$ & $\begin{array}{c}12 \\
(20.00)\end{array}$ & $\begin{array}{c}15 \\
(25.00)\end{array}$ \\
\hline $\mathrm{c}$ & Lengthy procedures & $\begin{array}{c}46 \\
(76.67)\end{array}$ & $\begin{array}{c}45 \\
(75.00)\end{array}$ & $\begin{array}{c}32 \\
(53.33)\end{array}$ \\
\hline $\mathrm{d}$ & Lack of awareness about the cut off dates & $\begin{array}{c}25 \\
(41.67) \\
\end{array}$ & $\begin{array}{c}37 \\
(61.67) \\
\end{array}$ & $\begin{array}{c}21 \\
(35.00) \\
\end{array}$ \\
\hline e & Delay in payment of indemnity & $\begin{array}{c}50 \\
(83.33)\end{array}$ & $\begin{array}{c}35 \\
(58.33)\end{array}$ & 0 \\
\hline $\mathrm{f}$ & $\begin{array}{l}\text { Insurance was not available for the farmer's } \\
\text { other crops }\end{array}$ & 0 & $\begin{array}{c}13 \\
(21.67)\end{array}$ & 0 \\
\hline g & Indemnity level was very less & $\begin{array}{c}33 \\
(55.00)\end{array}$ & 0 & 0 \\
\hline 5 & $\begin{array}{l}\text { No compensation was paid even if loss occurred } \\
\text { due to crop failure }\end{array}$ & $\begin{array}{c}54 \\
(90.00)\end{array}$ & 0 & 0 \\
\hline
\end{tabular}

The major constraints in the adoption of WBCIS were lack of awareness of the scheme and its provisions (87 per cent) like crops covered, sum insured, premium charged and loss assessment method. In most cases, the deduction of premium from the loan amount was not informed to the borrowers and in some cases, the borrowers also did not take much care to know about the interest rate charged and deduction as premium from their accounts and so on. Therefore, the insurers and bankers are required to clarify all the details about the various components of WBCIS to the farmers. Majority of the farmers in the study area were growing a variety of crops, but WBCIS was available only for 
paddy and sugarcane and this prohibited the farmers in adopting insurance to the other crops which were also affected by weather variability but not permitted to have insurance coverage. Lengthy procedures to avail insurance coverage was the main constraint in adoption of insurance as expressed by 75 per cent WBCIS farmers 53.33 per cent of MNAIS farmers.

\section{Farmers' Suggestions to Refine the Crop Insurance Scheme}

The suggestions for improvement in implementation of the NAIS, WBCIS and MNAIS schemes are presented in Table 3. The beneficiary farmers highlighted several suggestions to refine the crop insurance scheme. A majority of NAIS beneficiaries (83 per cent) suggested that unit of insurance coverage should be village level or individual farmer level and they were not in favour of firka level. About 47 per cent of the beneficiaries suggested that there should be timely payment of compensation amount. A majority of the beneficiaries (43 per cent) suggested that there should be more number of crop cutting experiments, if individual based crop insurance was not practicable.

Table 3.

Suggestions of Beneficiary Farmers

\begin{tabular}{|c|c|c|c|c|}
\hline $\begin{array}{l}\text { S1. } \\
\text { No. }\end{array}$ & Particulars & $\begin{array}{l}\text { NAIS } \\
(n=60)\end{array}$ & $\begin{array}{l}\text { WBCIS } \\
(n=60)\end{array}$ & $\begin{array}{l}\text { MNAIS } \\
(\mathrm{n}=60)\end{array}$ \\
\hline 1 & Unit area may be individual or village level & $\begin{array}{c}50 \\
(83.33)\end{array}$ & 0 & 0 \\
\hline 2 & $\begin{array}{l}\text { Timely payment of compensation should be } \\
\text { ensured }\end{array}$ & $\begin{array}{c}28 \\
(46.67)\end{array}$ & $\begin{array}{c}32 \\
(53.33)\end{array}$ & 0 \\
\hline 3 & Crop insurance should not be compulsory & $\begin{array}{c}18 \\
(30.00)\end{array}$ & $\begin{array}{c}15 \\
(25.00)\end{array}$ & $\begin{array}{c}28 \\
(46.67)\end{array}$ \\
\hline 4 & $\begin{array}{l}\text { More number of crop cutting experiment } \\
\text { should be conducted }\end{array}$ & $\begin{array}{c}26 \\
(43.33)\end{array}$ & 0 & 0 \\
\hline 5 & $\begin{array}{l}\text { Weather stations should perform more } \\
\text { efficiently and their number should be } \\
\text { increased }\end{array}$ & 0 & $\begin{array}{c}44 \\
(73.33)\end{array}$ & 0 \\
\hline 6 & $\begin{array}{l}\text { Crop cutting experiment should be properly } \\
\text { carried out }\end{array}$ & 0 & 0 & $\begin{array}{c}27 \\
(45.00)\end{array}$ \\
\hline
\end{tabular}

The major suggestions made by the WBCIS respondents were quick settlement of claims to (53 per cent) and prompt information about the claim settlement to be sent to the farmers by the bankers. About 73 per cent of the beneficiary farmers suggested establishment of more number of 
weather stations and improvement in their functioning. Local representatives should be appointed to monitor and record the rainfall and temperature data. The major suggestions expressed by the MNAIS farmers were delinking crop insurance from the crop loan and conducting of crop cutting experiment (CCE) at the respective field as identified strictly following appropriate statistical procedures i.e., random selection of field according to the allotment of random number. However, in most cases, the respondents observed that, the team of government officials conducted the CCE along the road-side plots and not in an actual field number as identified by random number or following the appropriate statistical procedures.

\section{CONCLUSION}

Taking the results of the study into consideration, necessary steps should be taken up by the implementing agency and the agricultural department to conduct crop cutting experiments at the earliest possible and claims should be settled within one month after the receipt of the yield data. To make the scheme more administratively efficient, the implementing agency need to establish its branch offices atleast at district level for taking up monitoring and implementing the crop insurance schemes effectively. Besides, it should appoint its own staff at grass-root level to gain the confidence of farmers. Earnest efforts should be taken to make the farmers realize the real purpose of the scheme, beyond perceiving it as a mere fund granting developmental programme.

\section{REFERENCES}

Mani, K., Chandrasekaran, M. \& Selvanayaki, S. (2012). Adaptability of crop insurance schemes in Tamil Nadu. Agricultural Economics Research Review. 25(2), 279-290.

Manohari, P.L. \& Desai, G.R. (2015). Factors influencing farmers decision in rainfed areas. Journal of Extension Education. 27 (3), 5477-5484.

Mohanty, B.K. \& Sandeep, K. K. (2012). A perspective of crop insurance in India: Approaches and challenges. Journal of Economics, Commerce and Research. 2(2), 25-33.

Palanisami, K., Ranganathan, C. R. \& Kakumanu, K. R. (2011). A Hybrid model to quantify the impact of climate change on agriculture in Godavari basin, India. Energy and Environment Research, 1(1), 32-52. 